\author{
JURNAL EINSTEIN \\ Jurnal Hasil Penelitian Bindang Fisika \\ Available online http://jurnal.unimed.ac.id/2012/index.php/inpafi \\ e-issn: $2407-747 x$, p-issn $2338-1981$
}

\title{
KONSTRUKSI TIMBANGAN DIGITAL MENGGUNAKAN LOAD CELL BERBASIS ARDUINO UNO DENGAN TAMPILAN LCD (Liquid Crystal Display)
}

\author{
Ridwan Abdullah Sani dan Andy Imanuel Maha \\ Jurusan Fisika, Fakultas Matematika dan Ilmu Pengetahuan Alam, Universitas Negeri Medan, \\ Indonesia \\ ridwanunimed@gmail.com
}

Diterima April 2017; Disetujui Mei 2017; Dipublikasikan Juni 2017

\begin{abstract}
ABSTRAK
Load cell banyak digunakan sebagai sensor pada timbangan digital. Namun, timbangan digital yang tersedia pada umumnya tidak menyediakan fasilitas untuk memori. Fasilitas penyimpanan data secara digital dibutuhkan untuk beberapa aplikasi. Penelitian ini bertujuan untuk mengembangkan timbangan digital ini menggunakan load cell berbasis Arduino Uno dengan tampilan LCD dan kemampuan menyimpan data. Pada penelitian ini digunakan perangkat keras (hardware): sensor load cell, Arduino Uno, Mikrokontroler ATMega328, HX711, dan LCD. Sistem kerja timbangan dimulai dengan menerima tegangan dari load cell yang diberi beban, kemudian sinyal diteruskan ke HX711 sebagai penguat sinyal, dan diteruskan melalui ADC Arduino. Selanjutnya, sinyal diolah menggunakan ATMega328 yang diprogram dengan bahasa C pada Arduino Uno untuk dapat ditampilkan pada LCD dan disimpan pada memori. Konstruksi timbangan digital dengan menggunakan load cell berbasis Arduino Uno dengan menggunakan tampilan LCD (Liquid Crystal Display) berhasil dibuat dengan hasil uji yang telah memenuhi standard. Hasil pengujian timbangan digital telah dilakukan dengan rata - rata persentase kesalahan sebesar 0,39\%. Perhitungan pengukuran massa yang mampu dideteksi adalah pada rentang 189,09 gr hingga 449,27 gr dengan tingkat kepercayaan 95\%.
\end{abstract}

Kata Kunci : Sensor Load Cell, HX711, Arduino Uno, Mikrokontroler ATMega328, dan LCD

\section{PENDAHULUAN}

Seiring dengan perkembangan teknologi dan ilmu pengetahuan, bidang elektronika mengalami kemajuan yang pesat dan memberikan kemudahan bagi manusia untuk memenuhi kebutuhan hidup sehari-hari. Kemajuan tersebut, membuat manusia dapat memanfaatkan teknologi yang ada untuk mempermudah kehidupannya, misalnya dalam hal pengukuran massa (Hidayani, dkk, 2013). Digitalisasi alat ukur analog telah dilakukan untuk memperoleh hasil yang lebih akurat dan mempermudah penggunaan alat ukur. Salah satu piranti ukur yang dialihkan dari analog ke digital adalah timbangan (Kamirul, dkk, 2015).

Timbangan digital dapat dibuat dengan menggunakan load cell yang merupakan sensor gaya berbasis pada bahan piezoelektrik. Load cell banyak digunakan dalam industri yang memerlukan peralatan untuk mengukur massa. Secara umum, load cell dan sensor gaya berisi pegas logam mekanik dengan mengaplikasikan 
beberapa keping strain gauges (SG), misalnya keping dari bahan piezoelektrik. Sinyal listrik yang dihasilkan oleh load cell berkorelasi dengan gaya yang diterima oleh pegas mekanik muncul sebagai pengaruh dari pembebanan yang ditransmisikan pada strain gauges. Sinyal yang dihasilkan dari load cell adalah dari perubahan resistansi strain gauge yang linear dengan gaya yang diaplikasikan (Rukmana, dkk, 2014).

Pengembangan alat timbangan digital dengan kemampuan tambahan dibutuhkan dalam kegiatan penelitian dan pengukuran tercatat. Piranti timbangan yang tersedia di pasaran tidak mendukung kebutuhan tersebut. Oleh sebab itu diperlukan pengembangan alat timbangan digital dengan menggunakan load cell dengan Arduino Uno, yang dilengkapi dengan kemampuan tambahan yang dibutuhkan.

\section{METODE PENLITIAN}

Penelitian ini dilakukan dengan membuat rancangan sesuai kebutuhan. Rancangan alat dibuat dengan beberapa diagram blok. Selanjutnya, konstruksi alat dilakukan dengan menggunakan komponen utama sebagai berikut: mikrokontroler, modul Arduino Uno, Load Cell, penguat intrumentasi, dan LCD. Peralatan penelitian ini terdiri dari 3 blok, yaitu:

\section{Rangkaian Sensor Massa (Load Cell)}

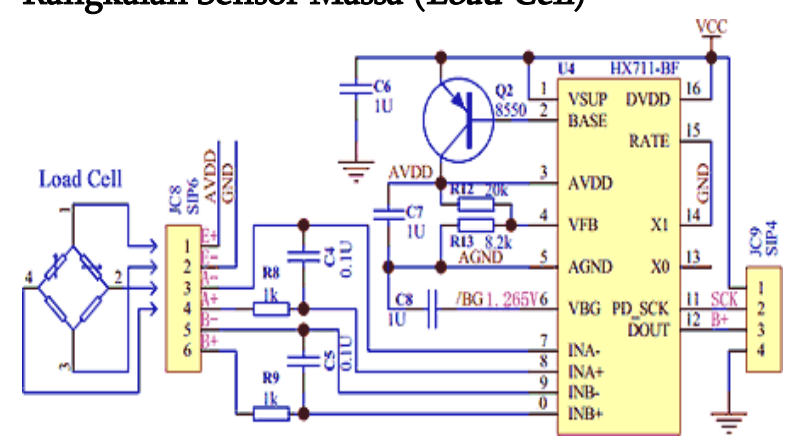

Gambar 1. Skematik Load Cell

Load cell adalah tranduser yang digunakan untuk mengubah tekanan menjadi sinyal elektrik.

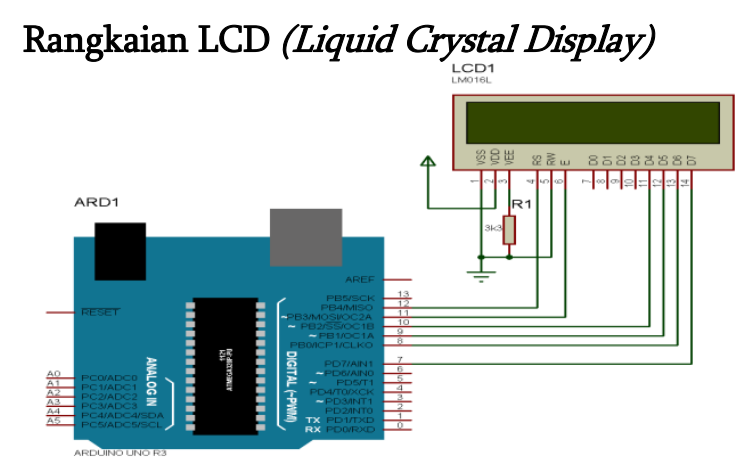

Gambar 2. Rangkaian LCD (Liquid Crystal Display)

Rangkaian Alat dengan modul Arduino Uno

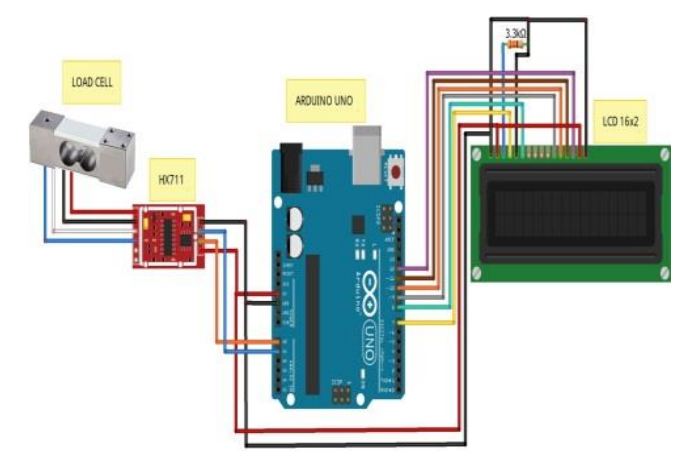

Gambar 3. Load Cell yang dihubungkan dengan Arduino Uno

\section{HASIL DAN PEMBAHASAN}

Skema rangkaian yang telah dirancang, selanjutnya dibuat dalam bentuk nyata, seperti pada gambar berikut :

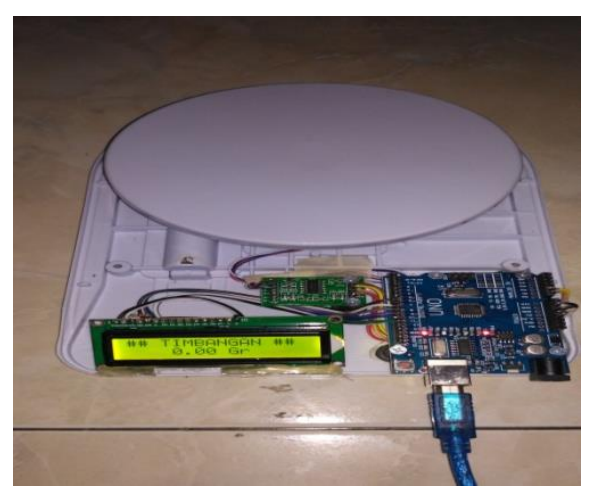

Gambar 4. Bentuk fisik timbangan digital yang telah dibuat

\section{Pengujian Rangkaian Pengkondisi Sinyal}

Pengujian rangkaian pengkondisi sinyal bertujuan untuk mengetahui apakah rangkaian yang dihasilkan rangkaian pengkondisi sinyal tersebut sudah sesuai dengan rangkaian yang diinginkan dan menguji kestabilan rangkaian tersebut. Berikut merupakan tabel hasil pengujian 
rangkaian pengkondisi sinyal terhadap beban yang diberikan.

Tabel 1. Hasil pengujian pengkondisi sinyal terhadap beban

\begin{tabular}{ccc}
\hline No & $\begin{array}{c}\text { Beban yang } \\
\text { diberikan } \\
\text { (gram) }\end{array}$ & $\begin{array}{c}\text { Output } \\
\text { pengkondisi } \\
\text { sinyal (mV) }\end{array}$ \\
\hline 1 & 0 & 0,74 \\
2 & 50 & 127 \\
3 & 100 & 164 \\
4 & 850 & 719 \\
5 & 900 & 759 \\
6 & 950 & 792 \\
7 & 1000 & 822 \\
8 & 1400 & 1156 \\
9 & 1450 & 1193 \\
10 & 1500 & 1231 \\
\hline
\end{tabular}

Pengujian ini dilakukan untuk mengetahui apakah port Arduino Uno berfungsi menampilkan 32 karakter pada LCD. Rangkaian Arduino Uno dihubungkan dengan LCD berukuran 16x2.

\section{Pengujian Keseluruhan Sistem Timbangan Digital}

Hasil pengujian pembacaan sensor terhadap timbangan standar sebagai berikut:

Tabel 2. Hasil pengujian timbangan digital

\begin{tabular}{|c|c|c|c|c|c|c|c|c|}
\hline \multirow[t]{2}{*}{ No. } & \multirow{2}{*}{$\begin{array}{l}\text { HPAS } \\
\text { (gram) }\end{array}$} & \multicolumn{5}{|c|}{ Hasil Pengukuran Alat (gram) } & \multirow{2}{*}{$\begin{array}{c}\text { Rata- } \\
\text { rata } \\
\text { pengu } \\
\text { kuran } \\
\text { gram }\end{array}$} & \multirow{2}{*}{$\begin{array}{l}\text { Persenta } \\
\text { kesalaha } \\
(\%)\end{array}$} \\
\hline & & I & II & III & $\overline{\mathrm{IN}}$ & $\mathrm{V}$ & & \\
\hline$T$ & 50 & 50,61 & 50,48 & 50,32 & 50,32 & 50,05 & 50,36 & 0,72 \\
\hline 2 & 100 & 100,05 & 100,75 & 100,64 & 100,72 & 101,05 & 100,82 & 0,82 \\
\hline 3 & 150 & 150,87 & 150,87 & 151,08 & 150,91 & 151,05 & 150,96 & 0,64 \\
\hline 4 & 200 & 201,63 & 201,63 & 201,54 & 201,93 & 201,17 & 201,58 & 0,79 \\
\hline 5 & 250 & 250,95 & 250,76 & 250,88 & 250,54 & 250,83 & 250,79 & 0,32 \\
\hline 6 & 300 & 300,23 & 300,06 & 300,14 & 300,49 & 300,40 & 300,26 & 0,09 \\
\hline 7 & 350 & 350,52 & 350,82 & 350,64 & 350,51 & 350,55 & 350,60 & 0,17 \\
\hline 8 & 400 & 400,84 & 400,84 & 401,16 & 401,13 & 401,02 & 401,10 & 0,02 \\
\hline 9 & 450 & 450,39 & 450,39 & 450,85 & 450,85 & 451,29 & 450,85 & 0,19 \\
\hline 10 & 500 & 500,79 & 500,79 & 500,74 & 500,91 & 500,35 & 500,65 & 0,13 \\
\hline
\end{tabular}

Cara menghitung rata-rata persentase tingkat kesalahan adalah dengan menggunakan persamaan:

$$
\sum E=\frac{\bar{E}-H P A S}{H P A S} \times 100 \%
$$

$\sum E=$ Rata-rata tingkat kesalahan
$\bar{E}=$ Rata-Rata Pengukuran

$H P A S=$ Hasil Pengukuran Alat Standar

Berdasarkan data yang diperoleh dalam penelitian, dapat dibuat grafik sebagai berikut.

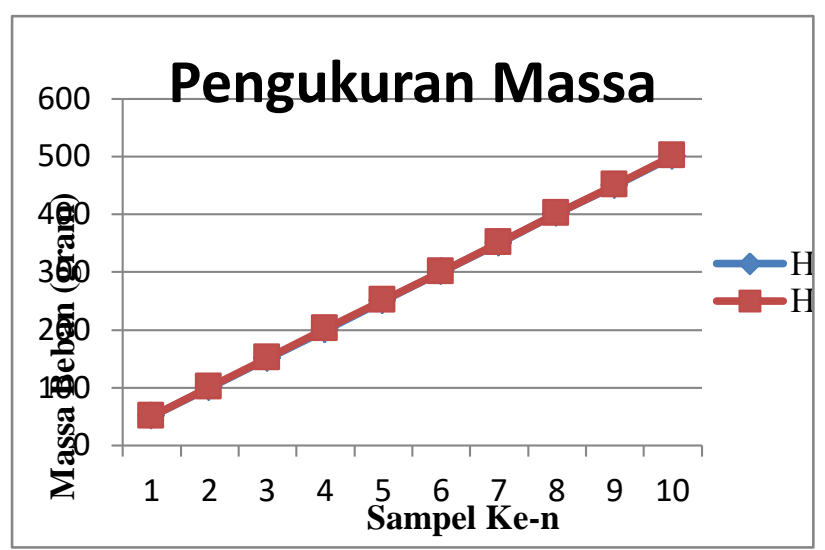

Gambar 5. Grafik Perbandingan HPAS dengan HPAR

\section{Pengujian Ketepatan (Repeatability)}

Beban uji yang dilakukan adalah beban yang bersifat tetap dengan muatan sekurangkurangnya $50 \%$ maks. Rumus ketepatan/repeatability yang digunakan adalah:

$$
R=\sqrt{\frac{\sum(P-\bar{p})^{2}}{n-1}}
$$

Tabel 3. Hasil pengujian ketepatan (repeatability)

\begin{tabular}{cccc}
\hline $\begin{array}{c}\text { Beban } \\
(\mathrm{L}) \\
(\text { gram })\end{array}$ & $\begin{array}{c}\Delta \mathrm{L} \\
(\text { gram })\end{array}$ & $\begin{array}{c}\text { Penunjuk } \\
\text { kan } \\
\text { Timbanga } \\
\mathbf{n}\end{array}$ & $\begin{array}{c}\text { Nilai } \\
\text { terbaca } \\
\left(\mathrm{I}_{\mathrm{L}+} \mathrm{L}\right) \\
(\mathrm{gram})\end{array}$ \\
\hline 50 & 0 & 50,60 & 50,60 \\
50 & 0 & 50,48 & 50,48 \\
50 & 0 & 50,36 & 50,36 \\
50 & 0 & 50,38 & 50,38 \\
50 & 0 & 50,68 & 50,68 \\
50 & 0 & 50,61 & 50,61 \\
50 & 0 & 50,72 & 50,72 \\
50 & 0 & 50,51 & 50,51 \\
50 & 0 & 50,42 & 50,42 \\
50 & 0 & 50,46 & 50,46 \\
\hline
\end{tabular}

Data hasil penelitian menunjukkan bahwa kesalahan alat masih cukup besar, yakni sekitar 0,39\%. Hal tersebut disebabkan karena pengaruh derau (noise) pada rangkaian penguat sinyal, sebelum diolah menjadi data digital.

\section{KESIMPULAN DAN SARAN}




\section{Kesimpulan}

Berdasarkan penelitian ini dapat diambil cell kemudian melakukan pengujian alat, maka dapat diambil kesimpulan sebagai berikut:

1. Timbangan digital menggunakan load cell yang digunakan sebagai penerima sinyal berupa tegangan analog dari beban berbasis Arduino Uno dapat bekerja dengan cukup bagus.

2. Persentase kesalahan pengukuran massa sebesar 0,39\%. Perhitungan pengukuran massa yang mampu dideteksi alat dengan baik adalah pada rentang 189,09 gram hingga 449,27 gram dengan tingkat kepercayaan 95\%.

\section{Saran}

Akurasi alat masih harus diperbaiki dengan menambah rangkaian penghilang derau (noise) pada penguat instrumentasi.

\section{DAFTAR PUSTAKA}

Hidayani, T.U., Tri. M., Abdul. R., Dedy. H., (2013), Rancang Bangun Timbangan Buah Digital Dengan Keluaran Berat dan Harga, Palembang: AMIK GI MDP.

Kamirul., Syahwanti, H., Nelvi, A., dan Hendro, M.S., (2015), Rancang Bangun Data Logger Massa Menggunakan Load Cell, Prosiding SKF 2015, ISBN : 978-60219655-9-7

Rukmana, I. C. A., Ro'uf. A., (2014), Aplikasi Sensor Load Cell pada Purwarupa Sistem Sortir Barang, Yogyakarta: FMIPA UGM., IJEIS, Volume 4, Nomor 1, April 2014, ISSN: 2088-3714 